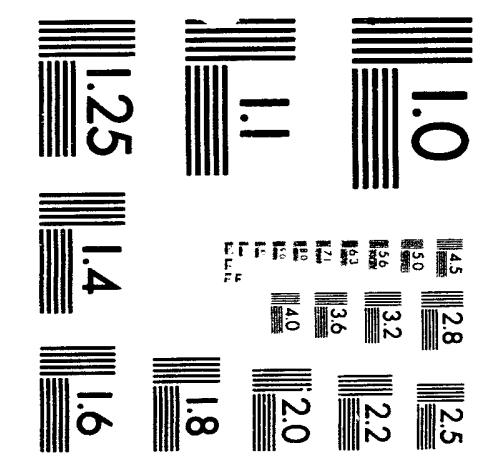



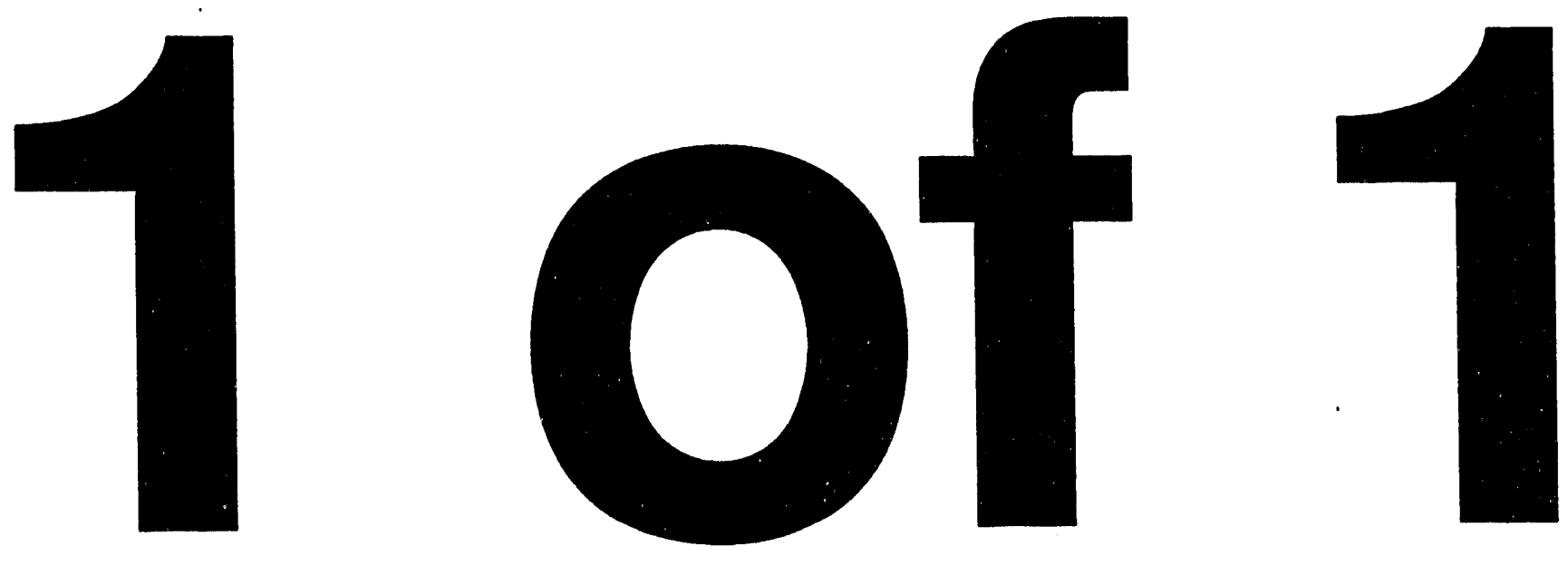


\title{
Proposal for the Completion of Outstanding Work on the Mechanical Absorber Structure of SDC Barrel Electromagnetic Calorimeter ${ }^{\dagger}$
}

\begin{abstract}
Victor Guarino, Norman Hill, Ted Kicmal*, James Nasiatka, Emil Petereit*, Lawrence Price, James Proudfoot, Robert Stanek
\end{abstract}

High Energy Physics Division

Argonne National Laboratory, Argonne, Illinois

David Scherbarth

Westinghouse Science and Technology Center

Pittsburgh, Pennsylvania

November 17, 1993

\section{Introduction}

The High Energy Physics Division at Argonne National Laboratory and Westinghouse Science and Technology Center, Pittsburgh Pennsylvania have worked jointly on a scintillating tile/fiber calorimeter with the SDC collaboration since it's inception in 1989. During the design and prototyping phase of the last three years, we have particularly worked on the development of an innovative cast lead approach to the absorber and the associated design of tile/fiber packaging for the barrel electromagnetic calorimeter (EMC). A full scale prototype program was initiated in 1992 to construct four EMC castings to be mated to respective steel

* T. Kicmal and E. Petereit are members of the Argonne Engineering Physics Division.

$\dagger \quad$ Work supported by the U.S. Department of Energy, Division of High Energy Physics, Contract W-31-109-ENG-38. 
hadronic wedges fabricated in China and presently at Fermilab. Up to the time that the second half funding was curtailed in FY 93, ANL was well on the way to completing these castings during 1993. All work, had been completed at that time except the final casting for the first full size lead absorber. This worl: included the design drawings, the structural analysis, the necessary testing of components, and the fabrication of most of the EMC module frame components. The only item remaining in this program was to complete the actual casting of the lead absorber. This step, which would lead to full confirmation of the design, was of course never completed. It is for this reason we are submitting this proposal asking that we be considered for funding to complete this step so that this unique concept can be used in the construction of future calorimeters.

Later in this proposal we outline in detail both the tasks that we have completed and those that we propose to complete in order to make the extensive investment in this technology useful to others in the field.

\section{Broposal}

The ANL High Energy Physics Division proposes to complete the casting of two SDC EMC modules. We would contract the completion of the necessary mold components, contract and oversee the completion of the casting furnace, and provide the necessary effort to assemble and fit up the module frames to the mold. In addition we would complete the required analysis and testing of the final castings to provide a basis for a final report to the SSC Laboratory or the Department of Energy as required. Although most tests have been completed, some final creep tests are contemplated to conclude this work. It should be noted in the following detail that the work to be completed is a carefully trimmed subset of work that was planned for FY 93 and 94 at the time that the SSC funding was terminated.

The technology and design developed for this calorimeter can potentially be directly transferred to other ongoing programs i.e., the STAR calorimeter for RHIC, the calorimeter for the CMS detector at CERN etc.

\section{Work Completed to Date}

1. Design and casting of two 18 cell lead castings

A. Tensile and Hardness test on 18 cell cast plates [Ref. 1].

B. Design drawings of 18 cell mold and casting (WSTC) [Ref. 2]. 
2. Design and Construction of two cast test beam models of the barrel EM Calorimeter
A. WSTC drawings of 10 tower mold [Ref. 3].
B. ANL drawings of 10 tower model [Ref. 4].
C. ANL drawings of testbeam transporter [Ref. 5].

3. Design and Casting of One 10 tower Mechanical Model of the EM Calorimeter
A. ANL drawings of 10 tower mechanical model [Ref. 6].
B. ANL drawings of 10 tower test stand [Ref. 5].

4. Completed FEA Analysis of the 10 Tower Mechanical Model
A. FEA analysis of 10 tower mechanical test mode [Ref. 7].

5. Carried out Mechanical Testing of the 10 Tower Model
A. Test results on 10 tower test model [Ref. 7-8].

6. Completed the Design of the Full Scale Pre-Production Prototype
A. ANL drawings of full scale prototype [Ref. 9].
B. ANL drawings of production fixtures [Ref. 10-11].
C. ANL drawings of module handling fixtures [Ref. 12-13].
D. ANL drawings of EMC to hadron interface [Ref. 14].
E. Analysis of full scale prototype [Ref. 15-23].

7. Completed Extensive Tensile and Creep Testing of Lead Alloys
A. Lead creep tests on lead and lead alloys [Ref. 24].
B. Tensile tests on lead and lead alloy [Ref. 25]. 
8 Fabrication of All of the Components Necessary to Complete Four EMC Erames

9. Completed the Assembly of EMC Frame \#1 in Preparation for Casting
A. QA data on EMC frame \#1

10. Completed Most of the Mold and Furnace Components in Preparation for Casting
A. WSTC drawings of mold and furnace parts [Ref. 26].
B. Thermal analysis of EMC frame during casting [Ref. 27].
C. WSTC thermal analysis of mold during casting [Ref. 28].

11. Completion of Test Castings
A. Bulkhead connection tests [Ref. 29].
B. Bulkhead connection test fixture drawings [Ref. 30].
C. High $\eta$ test casting drawings [Ref. 31].
D. High $\eta$ test casting results [Ref. 32].

\section{Proposed Work to Conclude Prototype Effort}

1. Complete Necessary Mold Components
A. Aluminum spacer plates for towers 3,6 , and 13
B. Showermax spacer plates
C. Mold perimeter plates
D. HAD1 filler plates
E. Frame clamps
F. Back alignment filler plates
G. Alignment plates 
2. Complete and Commission Furnace for Lead Casting
A. Furnace testing
B. Heat transfer tests
C. Test castings

3. Assemble Mold and Frame
A. Mold and frame preassembly
B. Disassembly and mold Release
C. Reassembly

4. Cast Two Prototype EMC Castings
A. Cast \#1 A EMC
B. Remove casting from mold and preparemold for Casting \#1B EMC
C. Cast \#1B EMC
D. Clean up and inspect castings

5. Mechanically Test Casting to Confirm Design and Specification

Perform tests to confirm FEA Analysis, verify tolerances, and check performance specifications

6. Complete Lead Creep Tests

Conduct ambient temperature creep tests to enhance elevated temperature tests.

7. Document and Publish Results of Prototype Program 


\section{Estimate Of Effort To Complete Work Listed}

\begin{tabular}{|c|c|c|c|}
\hline NAMIES & EFFORT (FTE) & DURATION & COST \\
\hline N. Hill & .1 & 9 months & $\$ 11,482$ \\
\hline V. Guarino & .2 & 9 months & $\$ 22,965$ \\
\hline J. Nasiatka & .2 & 9 months & $\$ 22,965$ \\
\hline E. Petereit & .1 & 5 months & $\$ 4,247$ \\
\hline L. Balka & .2 & 5 months & $\$ 12,758$ \\
\hline K. Woods & 1.00 & 5 months & $\$ 44,214$ \\
\hline C. Keyser & .5 & 5 months & $\$ 22,107$ \\
\hline TOTAL & & & $\$ 140,738$ \\
\hline
\end{tabular}

\section{Cost Estimate - Two Castings}

\begin{tabular}{|r|l|c|}
\hline & & Cost \\
\hline 1. & Complete Necessary Mold Components & $\$ 83,000$ \\
\hline 2. & Complete and Commission Furnace for Lead Casting & $\$ 76,000$ \\
\hline 3. & Complete Frame \# 2 & $\$ 14,000$ \\
\hline 4. & Assemble Mold and Frame \# 1 & $*$ \\
\hline 5. & Assemble Mold and Frame \# 2 & $*$ \\
\hline 6. & Cast Prototype EMC Casting \# 1 & $\$ 60,000$ \\
\hline 7. & Cast Prototype EMC Casting \# 2 & $\$ 50,000$ \\
\hline 8. & Mechanically Test Casting & $*$ \\
\hline 9. & Fixtures and Tooling & $\$ 15,000$ \\
\hline 10. & Complete Creep Tests & $*$ \\
\hline 11. & Document and Publish Results & $*$ \\
\hline 12. & Travel and Miscellaneous & $\$ 5,000$ \\
\hline 13. & Effort & $\$ 140,738$ \\
\hline & TOTAL & $\$ 443,738$ \\
\hline
\end{tabular}

* Effort costs included in Item 13 and Table at the top of the page. 


\section{REFERENCES}

1. Mechanical Testing of SDC 18 Cell Test Casting, J. Nasiatka, May 5, 1992.

2. Westinghouse Drawing Number 4136A43, 18 Cell Assembly.

3. Westinghouse Drawing Number 1D33449, 10 Tower Mold.

4. ANLHEP Drawing Number SSC-42-0, 10 Tower Test Model.

5. ANLHEP Drawing Number SSC-51-0, Adjusting Table Assembly.

6. ANLHEP Drawing Number SSC-2110-1-0, Mechanical Test Model.

7. SSC Laboratory Collaboration Meeting Presentation on EMC Cell Deflections, V. Guarino, April 20, 1993.

8. Memo on "Revised Test Plan for the 10 Tower Mechanical Model," J. Nasiatka, February 16, 1993.

9. ANLHEP Drawing Number 34-402-1-0, Full Scale Prototype Assembly.

10. ANLHEP Drawing Number 34-402-51-0, Front Plate Bending and Machining Fixture.

11. ANLHEP Drawing Number 34-402-52-0, HAD-1/Welding Fixture.

12. ANLHEP Drawing Number 34-402-53-0, EMC 1/64th Handling Fixture.

13. ANLHEP Drawing Number 34-402-54-0, EMC 1/32nd Handling Fixture.

14. ANLHEP Drawing Number 34-402-5-1, Adapter Plate.

15. Memo on "Analysis of Connections in EM Section," V. Guarino, September 29, 1992 .

16. Memo on "Analysis of EMC Module," V. Guarino, June 6, 1991.

17. $\quad$ "FEA Analysis Summary," V. Guarino, April 20, 1992.

18. Memo on "EM Frame Analysis to Reduce Cell Deflections", V. Guarino, October 14, 1992.

19. Memo on "Cell Deflections", V. Guarino, September 11, 1992. 
20. "Response to Concerns of the EM Review Committee", N. Hill, V. Guarino, J. Nasiatka, SDC-92-00299 and ANL-HEP-TR-92-67, August 1, 1992.

21. "Lead Deflections and Properties", V. Guarino, May 20, 1993.

22. Memo on "Scintillator Loading", V. Guarino, May 13, 1993.

23. Memo on "Brass Tubes", V. Guarino, February 5, 1993.

24. "Selection and Characterization of Lead Alloys for Use in the SDC EM Calorimeter", J. Nasiatka ANL-HEP-TR-93-90, November 4, 1993.

25. "Tensile Testing of Calcium Lead Alloys for the SDC Cast Lead Calorimeter", J. Nasiatka, September 14, 1992.

26. Westinghouse Drawing Number WSTC 2D29231, EM Prototype Mold.

27. Memo on "Thermal Analysis of EM Module Frame", V. Guarino, March 13, 1992.

28. Presentation to the Argonne Internal Review on Casting, D. Scherbarth, (Westinghouse Science and Technology Center), March 1, 1993.

29. Memo on "Strength of Lead Connection at Bulkhead", V. Guarino, October 19, 1992.

30. ANLHEP Drawing Number SSC-10-40-0, Test Mold.

31. ANLHEP Drawing Number SSC-2110-1-0, Mechanical Test Model $\eta=1.3$.

32. Memo on "High Eta Test Casting", V. Guarino, February 4, 1993.

\section{DISCLAIMER}

This report was prepared as an account of work sponsored by an agency of the I'nited States Government. Neither the United States Government nor any agency thereof, nor any of their employees, makes any warranty, express or implied, or assumes any legal liability or responsibility for the accuracy, completeness, or usefulness of any information, apparatus, product, or process disclosed, or represents that its use would not infringe privately owned rights. Reference herein to any specific commercial product, process, or service by trade name, trademark, manufacturer, or otherwise does not necessarily constitute or imply its endorsement, recommendation, or favoring by the United States Government or any agency thereof. The views and opinions of authors expressed herein do not necessarily state or reflect those of the United States Government or any agency thereof. 

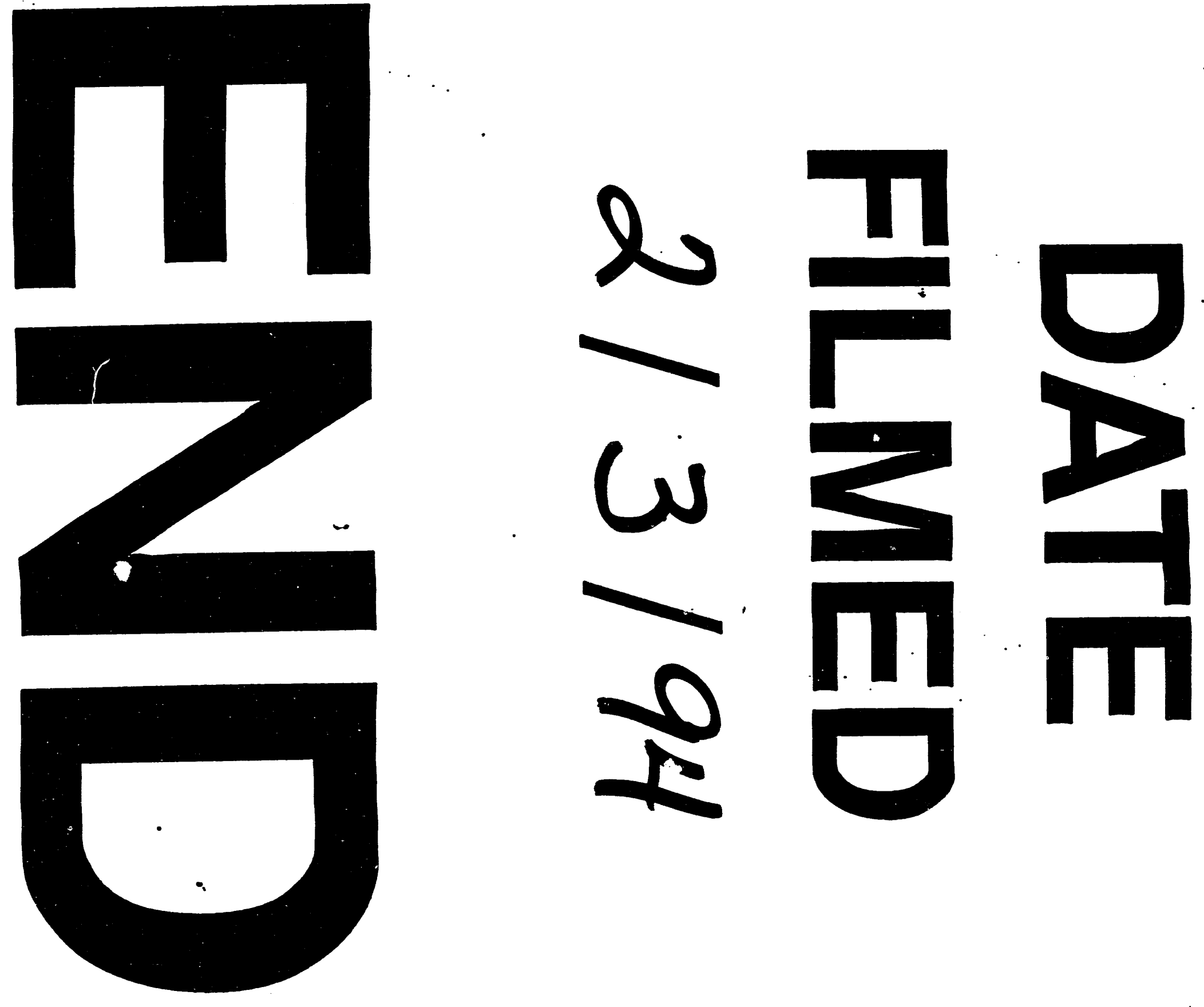
